Research Square
Preprints are preliminary reports that have not undergone peer review.

They should not be considered conclusive, used to inform clinical practice, or referenced by the media as validated information.

\title{
Hepatic Burdens of PCB and PCDD/F Congeners in Federally Endangered Shortnose Sturgeon and Atlantic Sturgeon from the Hudson River, New York, USA: Burden Patterns and Potential Consequences in Offspring
}

Isaac Wirgin ( $\square$ isaac.wirgin@nyumc.org )

NYU School of Medicine

R. Christopher Chambers

NOAA Fisheries

Research Article

Keywords: Hepatic Burdens, Potential Consequences, Endangered Shortnose

Posted Date: November 29th, 2021

DOI: https://doi.org/10.21203/rs.3.rs-1086966/v1

License: () (1) This work is licensed under a Creative Commons Attribution 4.0 International License. Read Full License 


\section{Abstract}

Sturgeon populations worldwide are threatened with extirpation but little is known about their tendency to bioaccumulate contaminants and their sensitivities to environmental burdens of these contaminants. Shortnose sturgeon and Atlantic sturgeon, two species that are federally endangered in the U.S., co-occur in the Hudson River (HR) where high sediment levels of PCBs and PCDD/Fs occur. Previous controlled laboratory studies showed that young life-stages of both species are sensitive to toxicities at low levels of TCDD and PCB126 exposure. The objective here was to measure congener-specific hepatic levels of PCBs and PCDD/Fs in HR specimens in order to determine if in situ bioaccumulation of these compounds was sufficiently high to cause the early life-stage toxicities previously observed. Estimates of hepatic burdens of PCBs and PCDD/Fs were obtained from a small number of specimens of each species collected between 2014 and 2016 and specimens of shortnose sturgeon collected over $30 \mathrm{yr}$ earlier and archived in a museum collection. Several significant patterns emerged. Hepatic levels of legacy PCBs and PCDDs were low in specimens of both species, but typically higher in shortnose than Atlantic sturgeon, a pattern consistent with their habitat use in the HR. Hepatic burdens from archived specimens of shortnose sturgeon tended to be higher than more recently collected ones despite expected reduction in their burdens due to preservation methods. Several inadvertent PCBs congeners were detected, including PCB11, but their possible toxicity to natural populations remains to be determined in future experiments. Levels of select PCDFs congeners, 2,3,7,8-TCDF and 2,3,4,7,8 PeCDF, were elevated in some shortnose sturgeon individuals from the HR. Using Relative Potency (ReP) factors derived from white sturgeon, the observed levels of some hepatic PCDFs in HR shortnose sturgeon may have been sufficiently high to impair recruitment of young life-stages in this ecosystem.

\section{Introduction}

Sturgeons (Acipenseridae) are an ancient taxon distributed throughout the Northern Hemisphere that has suffered severe declines in all 27 species. All sturgeons are listed on the IUCN Red List, and abundances of 22 of the 27 taxa continue to decrease (www.iucnredlist.org). Furthermore, 15 of the 27 taxa are listed as "Critically Endangered," the most threatened of all listing categories. Several factors have been proposed to explain these declines including overharvest, habitat loss (e.g., dam construction and channel dredging), vessel strikes, and chemical contamination. Many studies have examined the effects of the first three of these factors on declining population abundances, but few have investigated the impacts of chemical contaminants on toxic responses that may have contributed to these declines (Chambers et al. 2012).

Two species of sturgeons inhabit the Atlantic seaboard of North America - shortnose sturgeon (Acipenser brevirostrum) and Atlantic sturgeon (A. oxyrinchus oxyrinchus). Both are federal status species which protects them from harvest, restricts disturbance to their habitats, and consequently, limits the access of these species to researchers. Shortnose sturgeon was listed in 1973 under the U.S. Endangered Species Act (ESA) as endangered throughout its U.S. range. In 2012, Atlantic sturgeon was also listed under the ESA as endangered throughout all of its U.S. distribution except the Gulf of Maine (Federal Register 2012a, 2012b).

Shortnose sturgeon is amphidromous and usually resident within its natal estuaries throughout its life. It exhibits seasonal movements within the estuary and matures in the Hudson River (HR) at 3 to $4 \mathrm{yr}$ or at 6 to $8 \mathrm{yr}$ for in males and females, respectively (Bain 1997). Atlantic sturgeon is anadromous and highly migratory after its estuarine-resident juvenile life-stage which extends for 2 to 8 yr (Bain 1997; Caron and Tremlay 1999). The distance of its migrations in Atlantic coastal waters may be up to thousands of kilometers (Erickson et al. 2011; Wirgin et al. 2015) with returns to natal estuaries for spawning commencing at 6 to $8 \mathrm{yr}$ of age in southern populations and 25 to $30 \mathrm{yr}$ in northern ones (Dadswell 2006). Both species spawn demersal eggs in spring to early summer, occupy bottom habitats, and can live for decades, e.g., lifespans of both species in more northerly populations extend up to at least 60 yr (Gilbert 1989; Dadswell 2006; Dadswell et al. 1984). Historically, Atlantic sturgeon supported a robust commercial fishery in the Hudson River and nearby coastal waters until 1998 when coast-wide moratoriums on their harvest were imposed in state waters and along the entire Atlantic Coast.

Some of the largest populations of Atlantic Coast sturgeons occur in estuaries noted for high levels of sediment-borne chemical contaminants. For example, the HR is believed to host the largest population of Atlantic sturgeon (Waldman et al. 2018; Kazyak et al. 2020) and a relatively robust population of shortnose sturgeon (Bain 1997). The types and sources of contaminants prevalent in the HR include elevated levels of polychlorinated biphenyls (PCBs) released into the river for over four decades (1940s to the mid 1970s) from two General Electric electrical capacitor manufacturing facilities located 314 and 318 river kilometers (rkm) upstream from the river's mouth in New York City ( $\mathrm{rkm} 0$ ) (Figure 1). As a result, a 318-rkm reach of the mainstem of the HR was designated a federal Superfund site, the largest in the U.S. Trustees of the HR PCBs Superfund site are charged with determining if PCBs have caused damage to its resources, including its natural populations of fishes. Because of their protected status, there is particular concern regarding the potential damage from PCBs on HR sturgeon populations. The very protections afforded by the ESA, however, preclude the collection and sacrifice of these sturgeons for scientific studies, including estimation of the body burdens of contaminants and their potential for impairing these populations.

The HR ecosystem is also beset with high levels of polychlorinated dibenzo-p-dioxins (PCDDs). The main source of PCDDs was the Diamond Alkali manufacturing plant located next to the Passaic River in Newark, New Jersey, several miles upstream from Newark Bay. Newark Bay is contiguous with the HR via the Kill van Kull and New York Harbor (Figure 1). From 1951 to 1969, the Diamond Alkali facility produced herbicides and defoliants including Agent Orange. These industrial products leached from soils around the plant into the Passaic River and were subsequently transported downstream to Newark Bay and some migrated from there upstream into the adjacent Hackensack River. As a result, the lower Passaic River and Newark Bay are also designated as federal Superfund sites. The HR also contains elevated levels of polychlorinated dibenzofurans (PCDFs) from several sources including PCB production and incineration of municipal wastes.

Despite the cessation of the release of these contaminants in the mid 1900's, these contaminants persisted for decades and continue to be a concern for ecosystem and human health. They are highly lipophilic, bioaccumulative, and biomagnify which can result in high body burdens in piscivorous fishes. In the HR Estuary, high levels of total PCBs were regularly reported in finfishes that are desired for human consumption (Skinner 2011) and for some species that may be sentinels of ecological health (Fernandez et al. 2004). There is far less data on burdens of PCDD/Fs, but highly elevated hepatic levels were reported 
in one finfish species, Atlantic tomcod (Microgadus tomcod) (Fernandez et al. 2004) and several crustaceans, blue crab (Callinectes sapidus) and American lobster (Homarus americanus) (Hauge et al. 1994) from the Passaic River-Hackensack River-Newark Bay complex. To date, and largely because of their endangered status, there are no studies on levels of these contaminants - by class or congeners - in either sturgeon species in the HR Estuary nor on a congener-specific basis in any sturgeon worldwide. This paper begins to fill that void by taking advantage of the modest number of HR sturgeon samples ( $\mathrm{N}=$ 13) available from various sources over a three-decade period (1984 to 2016), and analyzing these samples for contaminants on a congener-specific basis.

Early life-stages of some fishes are very sensitive to toxicities from PCBs and PCDD/Fs. Finfish species (Elonen et al. 1988) and even populations within species (Nacci et al. 2010; Wirgin et al. 2011) are known to vary by orders of magnitude in their vulnerabilities to these contaminants. For example, lake trout (Salvelinus namaycush) exhibits the greatest sensitivity reported for any vertebrate taxon (Walker et al 2011) while other finfishes (e.g., zebrafish, Danio rerio) are far less sensitive (Henry et al. 1997).

These compounds exist in the environment as heterogeneous mixtures with differing levels of persistence among homologue classes and toxicities among congeners. Dioxin-like or coplanar congeners are believed to be most toxic due to their greater affinity to bind with the aryl hydrocarbon receptor (AHR) which is known to activate most of the early life-stage toxicities from these compounds. Unlike in mammals, there are at least two AHRs in fishes (AHR1 and AHR2), including both shortnose and Atlantic sturgeons (Roy et al. 2018ab), of which AHR2 is believed to be more important in mediating toxicities. The most toxic PCDD congener, 2,3,7,8 tetrachlorodibenzo-p-dioxin (TCDD), is used for computing the relative toxicities (Toxic Equivalency Factors, TEFs) of other PCB and PCDD/Fs congeners. In addition, recent studies indicate the presence in some environmental samples of several PCB congeners that are not part of legacy Aroclor mixtures but are byproducts during manufacturing of other products such as certain paint pigments and are called 'inadvertent PCBs' (Vorkamp 2016). The toxicities of inadvertent PCBs are only beginning to be evaluated (Roy et al. 2019).

Recent controlled laboratory studies investigated the sensitivities of early life-stages of several North American sturgeon species to toxicities from PCBs and PCDD/Fs exposures. Early life-stages of shortnose sturgeon and Atlantic sturgeon were sensitive at low doses of PCB126 and TCDD (as low > 0.1 parts per billion, ppb, and $>0.01 \mathrm{ppb}$, respectively) to induced cytochrome P4501A mRNA expression (Roy et al. 2011) and to some organismic responses critical to their condition and viability (Chambers et al. 2012). Similarly, in vitro and in vivo studies of white sturgeon ( $A$. transmontanus) and lake sturgeon ( $A$. fulvescens) demonstrated that they are among the more sensitive of finfishes to PCDD/Fs early life-stage toxicities (Doering et al. 2014; Doering et al. 2015;Doering 2016; Eisner et al. 2016).

A challenge encountered in such studies is linking the outcomes from experimental laboratory exposure studies to an environmental interpretation because of the near absence of data on tissue burdens of these contaminants in fishes in nature precisely due to their endangered status. Therefore, the objective in this study was to identify and assay the limited shortnose sturgeon and Atlantic sturgeon tissue samples from in situ collections usable for quantifying congenerspecific hepatic burdens of PCBs and PCDD/Fs. These data were then used to determine if these in situ concentrations of these compounds were sufficiently high to elicit the toxicities in young life-stages of these sturgeons observed in controlled laboratory studies. In addition, access to these estimates of hepatic burdens in HR sturgeons allowed us to examine patterns of relative hepatic burdens between the species and over time.

\section{Methods}

Listing of both sturgeon species under the U.S. ESA precluded us from sacrificing specimens for this study. Hence, the sample sizes of each species are limited to fatalities associated with bridge construction, a small set of non-destructively sampled fish from a previous study, and museum specimens. Nevertheless, even with a small sample size, these specimens allowed us to assess and relate trends in hepatic contaminant burdens to life history and habitat usage of these important threatened taxa, and to compare burdens in environmentally exposed specimens to concentrations that elicited toxic responses under controlled laboratory conditions.

We analyzed livers from a total of $13 \mathrm{HR}$ sturgeon specimens; eight were shortnose sturgeon and five were Atlantic sturgeon (Table 1). Specimens were obtained from three sources that differed in collection location, time, and means, and the status of the specimen for quantification of hepatic contaminant burdens. First, three archived shortnose sturgeon specimens were obtained from the New York State Museum, Albany, New York. These specimens were collected from the HR in the mid 1980s, initially stored in buffered formalin, and subsequently transferred to $95 \%$ ethanol. Second, seven live specimens (3 shortnose sturgeon and 4 Atlantic sturgeon) were collected and livers were obtained using laparoscopic biopsies. These individuals were collected in the Haverstraw Bay region (rkm 59-63) in September 2014 and April 2016, anesthetized (Matsche 2011), and a plug of liver tissue ( $\approx 100$ mg) obtained from each individual as described in Matsche (2013). Third, two recently dead shortnose sturgeon and one Atlantic sturgeon were collected in 2015 and 2016 from within $16 \mathrm{~km}$ of the Tappan Zee Bridge (rkm 44) by Allee, King, Rosen, and Fleming (AKRF), Inc. These specimens were collected as part of a retrieval program for sturgeon fatalities found during the construction of the Mario Cuomo Bridge (adjacent to and replacement for the Tappan Zee Bridge). All three fish had external injuries consistent with vessel strikes. Overall, the shortnose sturgeon specimens ranged from 33.3 to $88.3 \mathrm{~cm}$ fork length (FL) with all but one $>46$ $\mathrm{cm} \mathrm{FL}$, placing these fish in the adult size range (maturation occurs at 45 to $55 \mathrm{~cm} \mathrm{FL).} \mathrm{Atlantic} \mathrm{sturgeon} \mathrm{specimens} \mathrm{ranged} \mathrm{from} 42.7$ to $76.5 \mathrm{~cm} F \mathrm{~L}$ placing most of these specimens in the subadult range (subadults reported as 50 to $150 \mathrm{~cm} \mathrm{FL} \mathrm{(Bain} \mathrm{1997)).}$

Congener-specific PCB and PCDD/Fs analyses were conducted by AXYS Analytical Services, Sydney, British Columbia, Canada. Liver sample weights ranged from approximately $0.1 \mathrm{~g}$ to $25 \mathrm{~g}$. The liver samples were homogenized using dissection scissors to ensure complete extraction. Extraction and chromatographic clean-up procedures were performed in accordance with SGS-AXYS Method MLA-013: Analytical Method for The Determination of: Polybrominated Diphenyl Ethers, PCB Congeners, Chlorinated Pesticides, Technical Toxaphene, Toxaphene Congeners/Parlars and Polychlorinated Dibenzodioxins and Furans using Co-Extraction Techniques. Samples were fortified with isotopically labeled surrogate standards, and Soxhlet extracted in 1:1 Dichloromethane:Hexane for $16 \mathrm{hr}$. The resulting extract was gravimetrically split to reserve a portion as backup. Each resulting extract was spiked with 
clean-up standards, subsampled for lipid analysis, and then cleaned using a series of chromatographic columns. The clean-up columns generated separate fractions for the PCDD/F and PCB analyses.

Dioxin/furan analysis procedures were in accordance with USEPA Method 1613, Revision B, as documented in SGS AXYS Method MLA-017: Analytical Method for the Determination of Polychlorinated Dibenzodioxins and Dibenzofurans by EPA Method 1613B, EPA Method 8290/8290A or EPA Method DLM02.2. The fraction for PCDD/Fs analysis was concentrated and spiked with ${ }^{13} \mathrm{C}$-labeled recovery (internal) standards, for a final volume of $20 \mu \mathrm{L}$. The injection volumes were $1 \mu \mathrm{L}$ for the DB- 5 column analysis and $2 \mu \mathrm{L}$ for the DB- 225 confirmation analysis. The DB-5 capillary column (60 m, $0.25 \mathrm{~mm}$ i.d., 0.1 $\mu \mathrm{m}$ film thickness) was coupled to a high-resolution mass spectrometer (Waters Micromass Autospec Premier, Milford, MA). The mass spectrometer was tuned to a static mass resolution of $\geq 10,000$ in the electron impact ionization mode and data acquired in the voltage selected recording mode (SIR). A second instrumental analysis was performed using a DB-225 capillary column ( $30 \mathrm{~m}, 0.25 \mathrm{~mm}$ i.d., $0.15 \mu \mathrm{m}$ film thickness) coupled to a mass spectrometer (Waters Micromass Autospec Ultima) to confirm and/or quantify 2,3,7,8-TCDF and 1,2,3,7,8,9-HxCDD. This column was necessary to resolve non-toxic congeners that co-elute with 2,3,7,8-TCDF and 1,2,3,7,8,9-HxCDD on a DB-5 column. Analyte concentrations were quantified using MassLynx software (Waters, Milford, MA).

PCB congener analyses were in accordance with the USEPA Method 1668, Revision A: Chlorinated Biphenyl Congeners in Water, Soil, Sediment, and Tissue by HRGC/HRMS as documented in SGS AXYS Method MLA-010. The PCB fraction extract was further cleaned using Alumina chromatographic columns. The final extract was reduced in volume and spiked with ${ }^{13} \mathrm{C}$-labeled recovery (internal) standards prior to instrumental analysis. PCB extracts were concentrated to $20 \mu \mathrm{L}$, and $1 \mu \mathrm{L}$ was injected onto an SPB-Octly column ( $30 \mathrm{~m}, 0.25 \mathrm{~mm}$ i.d., $0.25 \mu \mathrm{m}$ film thickness) coupled to a high-resolution mass spectrometer (Waters Micromass Ultima). The mass spectrometer was tuned to a static mass resolution of $\geq 10,000$ in the electron impact ionization mode and data acquired in the voltage selected recording mode. Analyte concentrations were quantified using Micromass OPUSquan software.

All samples were analyzed in a single batch with associated QC samples consisting of a procedural blank and a lab-generated reference sample known as the Ongoing Precision and Recovery (OPR). The QC samples were prepared using canola oil as the matrix. The liver samples and the QC samples were prepared alongside each other and were subjected to the same analytical procedures. QC samples were evaluated against the analytical method criteria.

PCDD/Fs and PCBs homologue totals were obtained by summing the concentration of all detected congeners at each level of chlorination. Congener peaks that did not meet the method ion abundance ratio criteria were excluded from the homologue totals and Toxic Equivalent (TEQ) calculations. TEQs were calculated using WHO 1998 fish TEFs reported in Van den Berg et al. (1998).

We report means $( \pm$ SEM), sample sizes, and the number of samples for which concentrations were below the level of analytical detectability for each congener within a class, class totals, and summary TEQs. Statistical tests (one-way linear model) were conducted on two null hypotheses, $H_{0}$. $H_{01}$ was no difference in hepatic burden between time periods of collection (2010's vs. 1984). $H_{02}$ tested no difference between species (shortnose sturgeon vs. Atlantic sturgeon). For $H_{02}$, only fish from contemporaneous collections were used (i.e., 2010's). We used a significance level of $p<0.05$ throughout. However, because of small sample sizes ( $N=5$ and 5 for contemporaneous shortnose and Atlantic sturgeon, and $N=3$ for archived shortnose sturgeon specimens) and the further reduction in power of these low- $N$ tests due to a substantial fraction of contaminant assays falling below detectability levels, we also provide summaries of trends. Trends were summarized in three ways: 1) The proportion of congeners within a class where the mean hepatic concentration is significant in one of the two possible directions pertinent to the $\mathrm{H}_{0}, 2$ ) The proportion of mean directionality regardless of meeting the $p<0.05$ criterion, and 3 ) The ratio of the grand mean (mean of mean concentrations) of congener concentrations within each contaminant class. This latter assessment of trends provides an assessment of the magnitude of deviation from no difference between the groups being contrasted.

\section{Results}

Congener-specific hepatic PCB and PCDD/F concentrations ( $\mathrm{pg} / \mathrm{g} \mathrm{ww}$ ) were successfully obtained for all 13 sturgeon specimens including the three shortnose specimens from archived museum collections from the mid 1980's. There were, however, a number of hepatic concentrations below analytical detectability (97 of 267 congener-specific assays or $27 \%$ of all cases).

Regarding legacy coplanar PCB congeners, significantly greater hepatic concentrations were found in shortnose sturgeon than in Atlantic sturgeon collected contemporaneously during 2014 to 2016 for 9 of 11 dioxin-like congeners (Table 2). The overall hepatic coplanar PCB congener concentration (ratio of grand means across all individual PCB congeners) was 5.4 times higher in shortnose sturgeon than Atlantic sturgeon for the 11 congeners tested and 5.8 times higher for total PCBs (Table 2). Hepatic concentrations of individual dioxin-like PCB congeners were not significantly different in archived specimens (1980's) versus collections made in the 2010's but 7 of 11 congeners (and the total PCB levels) were higher in archived samples. The overall hepatic dioxin-like PCB congener concentration was 3.4 times higher in archived versus recent specimens and 1.4 times higher for total PCBs.

We also report hepatic concentrations of three inadvertent PCB congeners: PCB5, PCB11, and PCB52 (Table 2). Concentrations of PCB11 and PCB52 were high in both species and significantly higher (over five to nearly seven-fold) in contemporary shortnose sturgeon than Atlantic sturgeon specimens. For example, the mean hepatic level of PCB11 was $398 \mathrm{pg} / \mathrm{g}$ ww in shortnose sturgeon compared to $60 \mathrm{pg} / \mathrm{g}$ ww in Atlantic sturgeon. Similarly, the mean hepatic level of PCB52 was $346,250 \mathrm{pg} / \mathrm{g}$ ww in shortnose sturgeon compared to $64,300 \mathrm{pg} / \mathrm{g}$ ww in Atlantic sturgeon. Levels of PCB11 and PCB52 were also over four-fold higher in contemporary compared to archived shortnose sturgeon specimens.

Concentrations of the two dioxin-like congeners for which levels were detectable (PCB77, PCB81), were three (PCB77) to eight-fold (PCB81) higher in shortnose sturgeon than in Atlantic sturgeon although the PCB81 value for Atlantic sturgeon may be biased downward as four of the five observations were below detectability (Table 2). Concentrations of two other of the dioxin-like congeners (PCB126 and PCB169) were non-detectable in all sturgeon specimens except for one archived shortnose sturgeon specimen collected in 1984 near Albany, NY (rkm 232) which had a high PCB126 burden (38.4 pg/g ww). PCB126 was not detected in the other two archived specimens collected further downstream near Indian Point, NY (rkm 71) in the same year. PCB77 was the dominant of

Page $4 / 16$ 
the four dioxin-like congers in livers of recent shortnose sturgeon and Atlantic sturgeon (mean = 1,032 and 349 pg/g ww, respectively) and was comparably high in the archived shortnose sturgeon specimens (mean $=969 \mathrm{pg} / \mathrm{g} \mathrm{ww}$ ).

Hepatic burdens of PCDDs were low and variable among all HR groups (Table 3). Hepatic burdens of TCDD, the most toxic PCDD congener, were relatively low and variable with concentrations for individuals ranging from non-detectable to $2.72 \mathrm{pg} / \mathrm{g} \mathrm{ww}$ (Atlantic sturgeon), the highest group mean (1.71 pg/g ww) was for recent shortnose sturgeon but without significant differences between Atlantic sturgeon and shortnose sturgeon or between contemporary versus archived shortnose sturgeon. The highest mean PCDD concentrations were for OctaCDD in recent and archived shortnose sturgeon ( 9.3 and 178 pg/g ww, respectively), and in Atlantic sturgeon ( $8.2 \mathrm{pg} / \mathrm{g} \mathrm{ww})$. A tendency was evident for greater levels in archived than recent specimens of shortnose sturgeon (factor of 4.8). The concentrations of 1,2,3,4,6,7,8 HeapTACDD were also relatively high and differed significantly between recent and archived shortnose sturgeon (with levels at 4.9 and $14.2 \mathrm{pg} / \mathrm{g}$ ww, respectively), and were also relatively high in Atlantic sturgeon (7.4 pg/g ww) (Table 3).

Mean hepatic burdens of PCDFs varied widely among the 10 congeners with highest concentrations for 2,3,7,8 TCDF, the most toxic PCDF congener, in all three HR sturgeon groups (Table 4). Recently collected shortnose sturgeon tended to have higher mean hepatic levels of 2,3,7,8 TCDF (26.2 pg/g ww) than archived ones $(20.0 \mathrm{pg} / \mathrm{g} \mathrm{ww})$, and contemporary shortnose sturgeon had significantly higher levels than those found in Atlantic sturgeon (11.1 pg/g ww). The hepatic level of 2,3,7,8-TCDF was also quite high (42.4 pg/g ww) in one of the two archived shortnose sturgeon specimens collected near Indian Point, New York in 1984. Levels of 2,3,4,7,8 PentaCDF were also relatively high (e.g., 6.3 and $4.9 \mathrm{pg} / \mathrm{g}$ ww for recent and archived shortnose sturgeon, respectively) and significantly higher in contemporary shortnose sturgeon than Atlantic sturgeon. Overall, archived specimens tended to have greater hepatic burdens of PCDFs than recent specimens (factor of 2.9) and shortnose sturgeon had modestly higher PCDFs concentrations than Atlantic sturgeon (factor of 1.5).

From these data, TCDD TEQs for PCBs and PCDD/Fs were derived for each sturgeon specimen using WHO TEFs for fishes (Van den Berg et al. 1998), summary statistics calculated, and contrasts performed (Table 5). Mean hepatic TCDD TEQs were higher for PCDD/Fs than PCBs for both HR sturgeon species (Table 5). Among recently collected specimens, shortnose sturgeon had significantly higher TCDD TEQs for PCBs than those for Atlantic sturgeon (means: 1.6 vs. 0.3). Archived shortnose sturgeon specimens tended to have higher TCDD TEQs for PCBs than recent specimens; indeed, the highest two TCDD TEQs for PCBs (8.45 and 3.30) in shortnose sturgeon were both from archived specimens collected near Indian Point, New York (rkm 69) in 1984 while the lowest value for shortnose sturgeon (0.386) was also observed in an archived specimen collected in 1984 but much further upstream, near Albany, New York (rkm 229).

The between-species difference in TCDD TEQs for PCDD/Fs was marginally significant with values generally higher in shortnose sturgeon than Atlantic sturgeon (6.58 vs 3.48, respectively). The lowest TCDD TEQ for PCDD/Fs (0.799) was in an Atlantic sturgeon collected in 2016 from Haverstraw Bay (rkm 5963) while the two highest values were observed in shortnose sturgeon; an archived specimen (9.29) collected near Indian Point in 1984 and a recent shortnose sturgeon specimen (9.17) collected in 2015 at Nyack, New York (rkm 43).

Total TCDD TEQs were also significantly greater, by over twofold, in shortnose sturgeon than Atlantic sturgeon specimens (Table 5). Archived and recent specimens of shortnose sturgeon were comparable in average concentration ( 9.01 vs 8.16 , respectively).

TCDD TEQs were also calculated for 2,3,7,8 TCDF and 2,3,4,7,8 PeCDF, and their sum based on Eisner et als. (2016) relative potency (ReP) value developed from AHR2 activation in white sturgeon liver explants (PeCDF=1.4 and TCDF=1.2). Among recently collected specimens, shortnose sturgeon had significantly higher TCDD TEQs for 2,3,7,8 TCDF than those for Atlantic sturgeon (means: 36.65 vs. 15.58) (Table 6). Archived shortnose sturgeon specimens tended to have lower TCDD TEQs for 2,3,7,8 TCDF than recent specimens, but this difference was not significant; but the highest TCDD TEQ for 2,3,7,8 TCDF in shortnose sturgeon (59.36) was from an archived specimen collected off Indian Point, NY (rkm 69) in 1984 while the lowest value for shortnose sturgeon (5.50) was also observed in an archived specimen collected in 1984 but further upstream (near Albany, NY at rkm 229). The values of TCDD TEQs for 2,3,4,7,8 PeCDF were also significantly higher in shortnose sturgeon than Atlantic sturgeon (7.51 vs 2.75, respectively). The lowest TCDD TEQ for 2,3,4,7,8 PeCDF (0.96) was in an Atlantic sturgeon collected in 2016 from Haverstraw Bay (rkm 59-63) while the highest value was observed in a shortnose sturgeon; an archived specimen (11.92) collected near Indian Point, New York. TCDD TEQs for the sum of these two PCDFs was also significantly greater, by over twofold, in shortnose sturgeon than Atlantic sturgeon specimens (Table 6).

\section{Discussion}

\section{Specimen collections}

This study provides the first quantification of the congener-specific levels of PCBs and PCDD/Fs in any environmentally exposed sturgeon species worldwide and serves as an initial evaluation of the potential of their effects on the success of early life-stages and recruitment to adult populations. Even with the prohibition of sacrificing specimens for study, we obtained a limited, yet sufficiently large collection of specimens to address our objectives. Our unique sources of specimens included a carcass retrieval program associated with bridge construction on the HR, biopsying specimens using laparoscopy, and archived museum specimens. This unique data resource on bioaccumulation of PCBs and PCDD/Fs by sturgeons in a highly contaminated environment establishes a context for prior and future experimental studies of the biological consequences of their exposure to environmentally relevant levels and classes of contaminants, and offers important insights about differences between species. Despite the limited number of samples available to us, our analyses allowed us to extract significant patterns and trends pertinent to species, location, and temporal differences

Relationship between concentrations of contaminants in environmentally-exposed specimens and those that incurred toxicities in laboratory exposures

The primary objective of our study was to determine if levels of coplanar PCBs and PCDD/Fs in environmentally exposed sturgeons from the HR were at or near levels that caused the significantly induced CYP1A mRNA expression (Roy et al. 2011) and early life-stage toxicities observed in our earlier controlled 
laboratory experiments (Chambers et al. 2012). Activation of the aryl hydrocarbon receptor 2 (AHR2) is required to mediate most early life-stage toxicities from coplanar PCB and PCDD/F exposures in fishes, including these sturgeon species (Roy et al. 2018a), and induction of CYP1A is considered a reliable indicator of AHR2 activation. Roy et al. (2011) reported that the lowest nominal waterborne concentrations of PCB126 and TCDD tested in our experiments (0.01 ppb and $0.001 \mathrm{ppb}$, respectively) significantly induced CYP1A mRNA expression in shortnose sturgeon and Atlantic sturgeon larvae (Table 7).

Furthermore, Chambers et al. (2012) demonstrated that a variety of early life-stage toxicities in larval shortnose sturgeon and Atlantic sturgeon significantly increased in prevalence at nominal waterborne concentrations from 0.01 to $0.1 \mathrm{ppb}$ PCB126 and from 0.001 to $0.01 \mathrm{ppb} 2,3,7,8$ TCDD (Table 7 ). Thus, these laboratory studies suggested that early life-stages of both HR sturgeon species were among the more sensitive of fishes to the toxic effects of PCBs and PCDDs through activation of AHR2.

How do TCDD TEQs for hepatic coplanar PCBs and PCDDs in environmentally-exposed sturgeons from the HR compare to those that elicited significant CYP1A mRNA induction and early life-stage toxicities in the controlled laboratory experiments? Mean hepatic TCDD TEQs from PCDD/Fs and PCBs in contemporary collections of environmentally exposed sturgeons from the HR was 3.8 for Atlantic sturgeon and 8.2 for shortnose sturgeon (Table 5). The hepatic burdens of TCDD TEQs in both species were sufficiently high to induce the significant CYP1A mRNA expression previously observed (Roy et al 2011). But, the mean hepatic burdens of coplanar PCBs alone expressed as TCDD TEQs (0.31 to 1.6) may not have been sufficiently high to induce significant CYP1A expression in larval sturgeons. Levels of total TCDD TEQs that elicited the sublethal early life-stage toxicities listed in Table 7 varied between 1 TCDD TEQ for impaired eye development in shortnose sturgeon to 100 TCDD TEQs for impaired eye development in Atlantic sturgeon (Chambers et al. 2012). A mean of 10 TCDD TEQs significantly decreased length and abbreviated larval life span in controlled laboratory experiments with young life-stages of both shortnose sturgeon and Atlantic sturgeon (Chambers et al. 2012). Thus, hepatic burdens of TCDD TEQs in environmentally exposed sturgeons were potentially sufficiently high to activate some AHR-mediated sublethal toxicities in sturgeons from the Hudson River. However, the contribution of hepatic coplanar PCBs to the total TCDD TEQs was probably insufficient to induce toxicities on their own. Actual levels of TCDD TEQs in environmentally exposed HR sturgeon embryos and larvae will remain a major unknown because of strict limitations on their capture and their small size.

The World Health Organization (WHO) has developed TEFs for PCDFs in fishes (Van den Berg et a;/ 1998) including 2,3,7,8 TCDF (TEF=0.05) and 2,3,4,7,8 PeCDF (TEF=0.5), two of the PCDFs at relatively high concentrations in HR sturgeons. Although the toxicities of PCDFs have not been empirically addressed in either HR sturgeon species, the relative potency (ReP) (a measure of activity of individual congeners compared to that of TCDD) of 2,3,7,8 TCDF and 2,3,4,7,8 PeCDF were quantified by in vitro activation of AHR2 in white sturgeon Acipenser transmontanus (Doering 2016; Eisner et al. 2016). They reported considerably higher ReP values for these two PCDFs in white sturgeon, TEF=1.4 and TEF=1.2 for 2,3,7,8 TCDF and 2,3,4,7,8 PeCDF, respectively than the WHO's TEFs for these congeners. Applying these white sturgeon derived RePs to hepatic burdens of these two PCDFs in HR sturgeons resulted in hepatic TCDD TEQs ranging from highs of 71.3 in one archived shortnose sturgeon and 64.9 in one contemporary shortnose sturgeon to lows of 6.6 in one archived shortnose sturgeon and 7.9 in one contemporary Atlantic sturgeon specimen. The mean hepatic TCDD TEQs for these two PCDFs based on the white sturgeon RePs was 44.16 for the five contemporary shortnose sturgeon, 18.33 for the five Atlantic sturgeon, and 33.68 for the three archived shortnose sturgeon.

We believe that the hepatic TCDD TEQs burdens based on these sturgeon-specific RePs for PCDFs were sufficiently high in environmentally exposed HR sturgeons to cause the toxicities that we observed in controlled laboratory experiments. Clearly, these burdens are sufficient to activate the AHR2 pathway in vivo in both HR sturgeons as exemplified by induction of CYP1A mRNA (Roy et al. 2011) and elicit the higher-level developmental defects (morphometric alterations, eye developmental anomalies, and abbreviated lifespan of unfed larvae) (Chambers et al. 2012) in larval HR sturgeons that occurred at nominal waterborne levels of TCDD TEQs in the range of concentrations of PCDFs measured in HR sturgeons (Table 7).

While levels of these PCDFs were high in the livers of adult shortnose sturgeon from the HR, the levels in the young life-stages, which are most vulnerable to their damaging effects, are unknown. The link between hepatic burdens in subadult and adult sturgeons reported here and the manifestation of toxicities to these PCDF congeners in offspring in nature likely lies in maternal transfer of congeners from female to ova to offspring. Even without direct measure of congener burdens in eggs of these sturgeons spawned in situ, such maternal transfer can be inferred from the reduced levels of hepatic burdens in females compared to males that are seen in another fish species from the HR (Courtenay et al. 1999) and white sturgeon from elsewhere (Gundersen et al 2015).

\section{Inadvertent PCBs in Hudson River sturgeons}

There is growing concern regarding the environmental prevalence of inadvertent PCBs (Vorkamp 2016). The seemingly ubiquitous presence of PCB11, a byproduct in the production of yellow paint pigments, occurs in terrestrial and aquatic ecosystems including the HR and its presence has raised concerns for its bioaccumulative properties and toxicity (Rodenburg et al. 2015). Although PCB11 toxicity is only beginning to be addressed, initial studies in rodent models suggest that it is neurotoxic (Sethi et al. 2018) and studies in zebrafish found it to be a partial agonist/antagonist of the AHR pathway that may modify the toxicity of co-occurring coplanar congeners (Roy et al. 2019). PCB11 was detectable in livers of both HR sturgeons and it was five-fold higher in shortnose sturgeon (mean $398 \mathrm{pg} / \mathrm{g} \mathrm{ww}$ ) than Atlantic sturgeon (mean $59.9 \mathrm{pg} / \mathrm{g} \mathrm{ww}$ ). While these concentrations are far lower than those that impacted AHR activity and inhibited CYP1A expression in zebrafish, they are in the range of concentrations that promoted dendritic growth in rat neurons. For context, levels of PCB11 in HR sturgeons were significantly lower than those detected in adult tomcod from nine locales in the mainstem river (mean $1255.7 \mathrm{pg} / \mathrm{g}$ ww) (Wirgin et al. unpublished data). Empirical elucidation of the toxicity of PCB11 and other inadvertent PCBs should be a future priority for managers of impacted systems such as the HR.

\section{Comparison of hepatic PCBs and PCDD/F levels in shortnose sturgeon and Atlantic sturgeon}

The overall levels of hepatic total and coplanar PCBs for contemporary collections of HR sturgeons were significantly higher ( five-fold) in shortnose sturgeon than in Atlantic sturgeon specimens, however, all of these levels of PCBs were lower than expected based on those reported in sympatric Atlantic tomcod in the HR (Fernandez et al 2004). Consistent with other studies in HR fishes (Courtenay et al. 1999; Fernandez et al. 2004), PCB77 was the 
predominant coplanar PCB congener whereas levels of PCB126 and PCB169 were usually non-detectable. PCB126, the congener with the highest TEF, was non-detectable in all sturgeon specimens with the exception of a relatively high concentration $(38.4 \mathrm{pg} / \mathrm{g} \mathrm{ww})$ in one archived shortnose sturgeon collected near Albany, NY (rkm 229). In contrast, PCB 126 was detectable and at relatively high levels in juvenile tomcod from nine locales in the mainstem HR (593 $\mathrm{pg} / \mathrm{g}$ ww to 2,282 pg/g ww (mean 1,395 pg/g ww)) (Fernandez et al. 2004).

The significantly higher levels of hepatic coplanar PCBs in shortnose sturgeon than Atlantic sturgeon for all congeners (except for PCB126 and PCB169 which were below detection levels) may be due to a combination of three factors. First, sediment-borne PCBs levels are higher at more upstream locales in the HR (Farley and Thomann 1998; Farley et al 2006) where shortnose sturgeon typically reside compared to those levels found further downstream where juvenile Atlantic sturgeon are usually found. Second, shortnose sturgeon have a nearly twofold greater embryonic period duration than Atlantic sturgeon under a common thermal regime which may be due to shortnose sturgeon spawning earlier in the year and have substantially greater eggs size. Lastly, for the sizes of sturgeon specimens used here (Table 1), all but one shortnose sturgeon was likely to have been mature and these adult shortnose sturgeon would likely have been older than the similarly sized, juvenile Atlantic sturgeon. If true, these shortnose sturgeon specimens would have been bioaccumulating PCBs for longer than the Atlantic sturgeon specimens.

\section{Comparison of PCB levels in archived and contemporary collections}

Mean levels of total hepatic coplanar PCBs tended to be greater in the archived (1984) shortnose sturgeon specimens than in recent specimens (higher in 7 of 11 congeners above detection levels and for total PCBs). This difference was even more apparent when all of the shortnose sturgeon were collected in the same general region from Nyack to Indian Point (rkm 43 to 69), i.e., excluding the sole archived individual collected near Albany (rkm 229). The trend of higher levels of hepatic PCBs in archived specimens, despite the expected underestimate bias due to loss of PCBs in fixatives, is consistent with the fact that levels of sediment total PCBs have declined significantly in the HR since their peak in the mid 1970s (Farley and Thomann 1998).

\section{$\underline{\text { Interspecific comparison of hepatic contaminant levels }}$}

The relatively low levels of PCBs found in sturgeons from the HR is intriguing as it contrasts with higher levels in the only other HR resident fish species, Atlantic tomcod, for which congener-specific hepatic PCB and PCDD/F data is available (Courtenay et al. 1999; Fernandez et al. 2004). Tomcod inhabit the tidal HR and are largely sympatric with shortnose sturgeon and pre-migratory juvenile Atlantic sturgeon. Despite sharing similar physical niches, the hepatic burdens of total and coplanar PCBs were considerably lower in sturgeons than in tomcod (Courtenay et al. 1999; Fernandez et al. 2004). For example, the mean total hepatic PCBs in pools of young-of-the-year (YOY) tomcod collected in 1998 at nine different locales in the mainstem HR (rkm 0 to 82 ) ranged from 7 to $34 \mathrm{ug} / \mathrm{g}$ ww compared to a mean of $8.6 \mathrm{ug} / \mathrm{g}$ ww in contemporary shortnose sturgeon and $1.48 \mathrm{ug} / \mathrm{g}$ ww in Atlantic sturgeon collections. Hepatic coplanar PCBs in tomcod were also dominated by PCB77, but at considerably higher levels than in HR sturgeons. The mean level of hepatic PCB77 in pooled adult tomcod from rkm 59 was $17,394 \mathrm{pg} / \mathrm{g}$ ww and 6,341 pg/g ww in males and females, respectively, and at least twice those values (31,674 pg/g ww) in YOY tomcod also collected from rkm 59 (Courtenay et al. 1999; Fernandez et al. 2004). This compares to means of $349 \mathrm{pg} / \mathrm{g}$ ww and $1,032 \mathrm{pg} / \mathrm{g}$ ww of PCB77 in recent shortnose sturgeon and Atlantic sturgeon of unknown gender, respectively. PCB 126, the congener with the highest TEF in fishes, was not detectable in any contemporary shortnose sturgeon or Atlantic sturgeon specimens but was detectable at relatively high levels in YOY tomcod at nine locales in the mainstem HR with hepatic concentrations ranging between 593 (rkm 82) to 2,282 pg/g ww (rkm 37).

Although these three species co-occur in the HR, their differences in life histories, temporal use of habitats, and diets may play a role in determining hepatic PCB burdens. Regarding life-history differences, all three taxa spawn demersal, adhesive eggs. The sturgeons spawn in upriver stretches (mostly upstream of rkm 125) in mid spring (shortnose sturgeon) to late spring-early-summer (Atlantic sturgeon). In contrast, tomcod spawn in early to mid-winter (DecemberJanuary) and its eggs are retained in the mid-river span ( $r k m 50$ to 90). The seasonal difference in spawning results in a two to four-fold longer embryonic period duration in tomcod ( 1 month) than in shortnose sturgeon (2 weeks) or Atlantic (1 week) sturgeon, respectively. The extent of direct exposure to sediments likely scales proportionately with embryonic period duration regardless of the ontogenetic stage(s) of embryos that are especially sensitive to these contaminants and of the water temperature. Sturgeons also differ dramatically from tomcod in lifespan and the proportion of the lifespan spent in early lifestages. First spawning of shortnose sturgeon occurs from 3 to $4 \mathrm{yr}$ (males) and 6 to $8 \mathrm{yr}$ (females) and maximum lifespan is up to $37 \mathrm{yr}$ for the HR population (Greeley 1937, Dadswell et al. 1984) where they remain as river residents throughout their lives. For HR Atlantic sturgeon, maturation occurs at ages of at least 12 and $15 \mathrm{yr}$ (males and females, respectively (Bain 1997) and after up to a decade at sea (Everly and Boreman 1999) with each subsequent spawning year interspersed by 1 to $5 \mathrm{yr}$ at sea. Maximum lifespan for HR Atlantic sturgeon is at least $30 \mathrm{yr}$ (Gilbert 1989). In contrast, HR tomcod mature in $1 \mathrm{yr}$ and few live longer than $2 \mathrm{yr}$ (McClaren et al. 1988). These dramatic differences in life-history scaling means that the embryonic period in Atlantic tomcod is a far greater proportion of maximum lifespan ( 3 to $6 \%$ ) than the same life-stage proportions in either sturgeon species ( $0.1 \%$ for both sturgeons). This 30 - to 60 -fold greater proportion of the embryonic period in tomcod versus sturgeon means a very reduced opportunity for contaminant depuration and that tomcod is far more likely to be influenced by conditions experienced during the embryonic period including exposure to sediments and the role played by maternal transfer of contaminants to offspring.

Regarding diet differences among the species, although sturgeons and tomcod are opportunistic generalist feeders, their diets differ due to seasonal and habitat differences of the same life-stages. The diets of early life-stages of both sturgeons are not well known (Dadswell et al. 1984), due to their protected status, but some insights into the diets of YOY and yearling HR sturgeon have been obtained from impinged specimens at HR power plants (Carlson and Simpson 1987) and lavage methods (Haley 1998). The diets of impinged YOY shortnose sturgeon collected from mid (rkm 106-107) and upper (rkm 228) HR locations (above the salt front) revealed a predominance of freshwater taxa including midge larvae (Chironomidae), amphipods, and isopods. Molluscs and oligochaetes were uncommon in YOY shortnose diets despite an oligochaete (Limnodrilus hoffmeisteri) being a community dominant in freshwater habitats likely used by sturgeons (Simpson et al. 1985). The diets of YOY and adult tomcod in the HR consist almost exclusively of invertebrate prey including calanoid copepods, gammarids, Neomysis sp., polychaetes, and Monoculodes (Nittel 1976; Grabe 1978; 1980). More information is needed on the amount 
and type of contaminant in the diets of young sturgeons and tomcod, and in the possible role of maternal transfer of contaminants to offspring. Clearly, maternal transfer of PCBs and PCDD/Fs is substantial in fishes, including HR tomcod (Courtenay et al. 1999), but has yet to be evaluated in either sturgeon species.

There was little evidence of elevated hepatic PCDDs in either of the two sturgeons from the HR. For example, the mean level of 2,3,7,8 TCDD was $1.71 \mathrm{pg} / \mathrm{g}$ ww in contemporary collections of shortnose sturgeon and $0.63 \mathrm{pg} / \mathrm{g}$ ww in Atlantic sturgeon. Four of the 10 sturgeon specimens failed to exhibit detectable levels of TCDD. Mean levels of hepatic TCDD in the archived shortnose sturgeon specimens was similarly low at $0.99 \mathrm{pg} / \mathrm{g}$ ww. Low levels of PCDDs, including TCDD, were expected in sturgeons from the mainstem HR because the major source of PCDDs to the lower Estuary was the former Diamond Alkali facility which was located adjacent to the Lower Passaic River, source water for Newark Bay in the western reaches of the Estuary and neither sturgeon species is common there (Wilk et al. 1997). Furthermore, $86 \%$ to $98 \%$ of total PCDDs in soils in the vicinity of the Diamond Alkali facility was $2,3,7,8$ TCDD (Umbreit et al. 1986; Wenning et al. 1993). The bioavailability of PCDDs to at least one member of the finfish community at the Diamond Alkali site was revealed by the near-record levels of hepatic PCDDs (mean 673 TCDD TEQs from PCDD), >80\% of which was TCDD, in tomcod from Newark Bay and the proximal Hackensack River (Courtenay et al. 1999; Fernandez et al. 2004). We are unaware of evidence of major transport of PCDDs from the Passaic River, downstream to Newark Bay, and through the Kill van Kull to the mainstem HR. Thus, low hepatic burdens of PCDDs in sturgeons in the mainstem HR is consistent with their life history and behavior.

Levels of some PCDFs, particularly those with potentially high TEFs in sturgeons, were greater than expected in shortnose sturgeon and in a single Atlantic sturgeon specimen. The mean level of 2,3,7,8 TCDF in recent shortnose sturgeon specimens was $26.18 \mathrm{pg} / \mathrm{g}$ ww and $11.13 \mathrm{pg} / \mathrm{g}$ ww in Atlantic sturgeon. Similarly, the mean level of 2,3,4,7, 8 PeCDF was $6.26 \mathrm{pg} / \mathrm{g}$ ww and $2.29 \mathrm{pg} / \mathrm{g}$ ww in recent specimens of shortnose sturgeon and Atlantic sturgeon, respectively. In previous studies of Atlantic tomcod, the ratios of PCDDs to PCDFs in tomcod were greater in tomcod from Newark Bay/Hackensack River than in fish from the mainstem HR where the opposite was true, i.e., hepatic burdens of PCDFs exceeded that of PCDDs in the HR (Fernandez et al. 2004). The same phenomenon was observed in sturgeons in this study. While we are unaware of specific sources of PCDFs in the mainstem HR, it has been shown that PCDFs are a co-contaminant in PCB formulations (O'Keefe et al. 1984).

\section{Conclusions}

Despite their bottom-dwelling lifestyle, longevity, and occurrence in the tidal HR estuary where levels of sediment-borne PCBs are high, HR sturgeons bioaccumulated relatively low levels of hepatic PCBs compared to sympatric species. We suggest that their failure to bioaccumulate high levels of these contaminants is a partial result of their diet and other unknown life history traits. Similarly, hepatic burdens of PCDDs in HR sturgeons were low, but that was consistent with their absence from locales where sediment levels of PCDDs are high. In contrast, burdens of select PCDFs were unexpectedly high in HR sturgeons and at levels that may cause toxicity in another North American sturgeon species. We suggest that future controlled laboratory studies be conducted to evaluate the concentrations of PCDFs that result in toxicity in young life-stages of HR sturgeons.

\section{Declarations}

\section{Acknowledgments}

This study was supported by a research grant from the Hudson River Foundation and funding from NOAA Protected Species. We also acknowledge support from NYU National Institute of Environmental Health Sciences Center Grant ES00260 and the continued support of the NOAA Northeast Fisheries Science Center. We thank Mark Matsche and Kevin Rosemary of the Maryland DNR and Fred Jacobs and Justin Krebs of AKRF, Inc. for their assistance in sample collections.

\section{Statements and Declarations}

\section{Funding}

This study was funded by a grant from the Hudson River Foundation and was supplemented with support from NOAA. Support of the Molecular Facilities Core of National Institute of Environmental Health Sciences Center Grant EHS00260 is also acknowledged.

\section{Competing Interests}

The authors have no relevant financial or non-financial interests to disclose.

\section{Author Contributions}

Drs. Wirgin and Chambers contributed equally to study conception and design. Sample acquisition and analyses by AXYS were coordinated by IW. The first draft of the manuscript was written by IW. Both authors read approve of the final manuscript.

\section{References}

Bain MD (1997) Atlantic and shortnose sturgeons of the Hudson River: common and divergent life history attributes. Environ Biol Fishes 48:347-358

Caron F, Tremblay S (1999) Structure and management of an exploited population of Atlantic sturgeon (Acipenser oxyrinchus) in the St. Lawrence estuary, Quebec, Canada. J Appl Ichthyol 15 
Carlson DM, Simpson KW (1987) Gut contents of juvenile shortnose sturgeon in the Upper Hudson Estuary. Copeia 1987:796-802

Chambers RC, Davis DD, Habeck EA, Roy NK, Wirgin I (2012) Early life-stage toxic effects of PCB126 and TCDD on shortnose sturgeon and Atlantic sturgeon. Environ Toxicol Chem 31: 2324-2337

Courtenay S, Grunwald C, Kreamer G-L, Fairchild WL, Arsenault JT, Ikonomou M, Wirgin I (1999) A comparison of the dose and time response of CYP1A1 mRNA induction in chemically treated Atlantic tomcod from two populations. Aquat Toxicol 47:43-69

Dadswell MJ (2006) A review of the status of Atlantic sturgeon in Canada, with comparisons to populations in the United States and Europe. Fisheries $31: 218-229$

Dadswell MJ, Taubert BT, Squiers TS, Marchette D, Buckley J (1984) Synopsis of biological data on shortnose sturgeon, Acipenser brevirostrum LeSueur 1818. NOAA Technical Report NMFS-14, FAO Fisheries Synopsis No. 140, 45p

Doering J (2016) Predicting the Relative Sensitivity of Sturgeon to Aryl Hydrocarbon Receptor Agonists. Ph.D. Thesis. Toxicology Graduate Program. University of Saskatchewan. $287 \mathrm{pp}$

Doering JA, Wiseman S, Beitel SC, Giesy JP, Hecker M (2014) Identification and expression of aryl hydrocarbon receptors (AhR1 and AhR2) provide insight in an evolutionary context regarding sensitivity of white sturgeon (Acipenser transmontanus) to dioxin-like compounds. Aquat Toxicol 150:27-35

Doering JA, Farmahin R, Wiseman S, Beitel SC, Kennedy SW, Giesy JP, Hecker M (2015) Differences in activation of aryl hydrocarbon receptors of white sturgeon relative to lake sturgeon are predicated by identities of key amino acids in the ligand binding domain. Environ Sci Technol 49:4681-4690

Eisner BK, Doering JA, Beitel SC, Wiseman S, Raine JC, Hecker M (2016) Cross-species comparison of relative potencies and relative sensitivities of fishes to dibenzo-p-dioxins, and polychlorinated biphenyls in vitro. Environ Toxicol Chem 35:173-181

Elonen GE, Spehar RL, Holcombe GW, Johnson RD, Fernandez JD, Erickson RJ, Tietge JE, Cook PM (1998) Comparative toxicity of 2,3,7,8 tetra- chlorodibenzop-dioxin to seven freshwater fish species during early life-stage development. Environ Toxicol Chem 17:472-483

Erickson DL, Kahnle A, Millard MJ, Mora EA, Bryja M, Higgs A, Mohler J, DuFour M, Kenney G, Sweka J, Pikitch EK (2011) Use of pop-up satellite archival tags to identify oceanic-migratory patterns for adult Atlantic sturgeon, Acipenser oxyrinchus oxyrinchus Mitchell, 1815. J Appl Ichthyol 27:356-365

Everly AW, Boreman J (1999) Habitat use and requirements of important fish species inhabiting the Hudson River Estuary: Availability of information. NOAA Technical Memorandum NMFS-NE-121

Farley KJ, Thomann RV (1998) Fate and bioaccumulation of PCBs in aquatic contaminants. pp.1581-1594 In Environmental Occupational Medicine, Rom, W.N. (ed.), Lippincott-Raven, Philadelphia, PA

Farley KJ, Wands JR, Damiani DR, Cooney III TF (2006) Transport, fate, and bioaccumulation of PCBs in the lower Hudson River. pp. 368-382. In: The Hudson River Estuary, Levinton JS and Waldman JR, eds, Cambridge University Press, NY

Federal Register (2012a) Endangered and threatened wildlife and plants; threatened and endangered status for distinct population segments of Atlantic sturgeon in the Northeast region, 77, 5880-5912, February 6, 2012

Federal Register (2012b) Endangered and threatened wildlife and plants; threatened and endangered status for two distinct population segments of Atlantic sturgeon Acipenser oxyrinchus oxyrinchus in the southeast. 77, 5914-5984, February 6, 2012

Fernandez MP, Ikonomou MG, Courtenay SC, Wirgin II (2004) Spatial variation in hepatic levels and patterns of PCBs and PCDD/Fs among young-of-the-year and adult Atlantic tomcod (Microgadus tomcod) in the Hudson River Estuary. Environ Sci Technol 38:976-983

Gilbert CR (1989) Species profiles: life histories and environmental requirements of coastal fishes and invertebrates (Mid-Atlantic Bight) - Atlantic and shortnose sturgeons. U.S. Fish Wildl Serv Biol Rep 82 (11.122). U.S. Army Corps of Engineers, TR EL82-4. 28 pp

Grabe SA (1978) Food and feeding habits of juvenile Atlantic tomcod, Microgadus tomcod from Haverstraw Bay, Hudson River. Fish Bull 76:89-94

Grabe SA (1980) Food of age 1 and 2 Atlantic tomcod from Haverstraw Bay, Hudson River. Fish Bull 77:1003-1006

Greeley J.R (1937) XI. Fishes of the area with annotated list. Pages 45-103 in A Biological Survey of the Lower Hudson Watershed. Supplement to 26th Annual Report, 1936. New York State Conservation Department, Albany, New York

Haley N (1998) A gastric lavage technique for characterizing diets of sturgeons. No Am J Fish Manage 18:978-981

Hauge PM, Belton TJ, Ruppel BE, Lockwood K, Mueller RT (1994) 2,3,7,8-TCDD and 2,3,7,8-TCDF in blue crabs and American lobsters from the Hudson-Raritan Estuary and the New York Bight. Bull Environ Contamin Toxicol 52:734-741

Henry TR, Spitsbergen JM, Hornung MW, Abnet CC, Peterson RE (1997) Early life stage toxicity of 2,3,7,8-tetrachlorodibenzo-p-dioxin in zebrafish (Danio rerio). Toxicol Appl Pharmacol 142:56-68 
Kazyak D, Flowers AM, Hostetter NJ, Madsen JA, Breece MW, Higgs A, Brown LM, Royle JA, Fox DA (2020) Integrating side-scan and acoustic telemetry to estimate the annual spawning run of Atlantic sturgeon in the Hudson River. Can J Fish Aquat Sci DOI: 10.1139/cjfas-2019-2039

Matsche M (2013) Relative physiological effects of laparoscopic surgery and anesthesia with tricaine methanesulfonate (MS-222) in Atlantic sturgeon Acipenser oxyrinchus oxyrinchus. J Appl Ichthyol 29:510-519

Matsche MA (2011) Evaluation of tricaine methanesulfonate (MS-222) as a surgical anesthetic for Atlantic sturgeon Acipenser oxyrinchus oxyrinchus. J Appl Ichthyol 27:600-610

McLaren JB, Peck TH, Dey WP, Gardinier M (1988) Biology of Atlantic tomcod in the Hudson River Estuary. American Fisheries Society Monograph 4:102112

Nacci D, Champlin D, Jayaraman S (2010) Adaptation of the estuarine fish Fundulus heteroclitus (Atlantic killifish) to polychlorinated biphenyls (PCBs). Estuaries Coasts 33:853-864

Nittel M (1976) Food habits of Atlantic tomcod (Microgadus tomcod) in the Hudson River. In Hudson River Ecology. Fourth Symposium on Hudson River Ecology. Bear Mountain, NY March 28-30, 1976. Hudson River Environmental Society

O'Keefe P, Hilker D, Meyer C, Aldous K, Shane L (1984) Tetrachlorodibenzo- $p$-dioxins and tetrachlorodibenzofurns in Atlantic Coast striped bass and in selected Hudson River fish, waterfowl and sediments. Chemosphere 13:849-860

Rodenburg L, Guo J, Christie R (2015). Polychlorinated biphenyls in pigments: inadvertent production and environmental significance. Colora Technol 131:353-369

Roy MA, Sant KE, Venezia OL, Shipman AB, McCormick SD, Saktrakulka P, Hornbuckle KC, Timme-Laragay AR (2019) The emerging contaminant 3,3'dichlorobiphenyl (PCB-11) impedes Ahr activation and CYP1a activity to modify embryotoxicity of Ahr ligands in the zebrafish embryo model (Danio rerio). Environ Pollut 254, Part A, November 2019, 113027

Roy, NK, Candelmo, A, DellaTorre, MS, Chambers, RC, Nadas, A and Wirgin, I. (2018a) Characterization of AHR2 and CYP1A expression in Atlantic sturgeon and shortnose sturgeon treated with coplanar PCBs and TCDD. Aquat Toxicol 197:19-31

Roy N, DellaTorre M, Candelmo A, Chambers RC, Habeck E, Wirgin II (2018b) Characterization of AHR1 and its functional activity in Atlantic sturgeon and shortnose sturgeon. Aquat Toxicol 205:25-35

Roy NK, Walker N, Chambers RC, Wirgin I (2011) Characterization and expression of cytochrome P4501A in Atlantic sturgeon and shortnose sturgeon experimentally exposed to coplanar PCB 126 and TCDD. Aquat Toxicol 104:23-31

Sethi S, Keil KP, Lein PJ (2018) 3,3'-Dichlorophenyl (PCB11) promotes dendritic arborization in primary rat cortical neurons via a CREB-dependent mechanism. Arch Toxicol 92:3337-3345

Simpson KW, Fagnani JP, DeNicola DM, Bode RW (1985) The freshwater macrobenthos of the main channel, Hudson River. Part A. General study description and results, including a discussion of organism-substrate relationships. Final report to Hudson River Foundation for Grant No. 8/83A/39. Hudson River Foundation, New York, $70 \mathrm{p}$

Skinner LC (2011) Distributions of polyhalogenated compounds in Hudson River (New York, USA) fish in relation to human uses along the river. Environ Pollut 159:2565-2574

Sloan RJ, Simpson KW, Schroeder RA, Barnes CR (1983) Temporal trends toward stability of Hudson River PCB contamination. Bull Environ Contamin Toxicol 31:377-385

Umbreit TH, Hess EJ, Gallo MA (1986) Bioavailability of dioxin in soil from a 2,4,5-trichlorophenoxyacetic acid manufacturing site. Science 232:497-499 Van den Berg and 23 coauthors (1998) Toxic equivalency factors (TEFs) for PCBs, PCDDs, PCDFs for humans and wildlife. Environ Health Perspect 106:775792

Vorkamp K (2016) An overlooked environmental issue? A review of the inadvertent formation of PCB-11 and other PCB congeners and their occurrence in consumer products and in the environment. Sci Total Environ 541:1463-1476

Waldman J, Alter SE, Peterson D, Maceda L, Roy NK, Wirgin II (2018) Contemporary and historical effective population sizes of Atlantic Sturgeon Acipenser oxyrinchus oxyrinchus. Conserv Genet 20:167-184

Walker MK, Spitsbergen J, Olson JR, Peterson RE (2011) 2,3,7,8-tetrachlorodibenzo-p-dioxin (TCDD) toxicity during early life stage development of lake trout (Salvelinus namaycush). Can J Fish Aquat Sci 48:875-883

Wenning R, Paustenbach D, Johnson G, Erlich R, Harris M, Bedbury H (1993) Chemometric analysis of potential sources of polychlorinated dibenzo- $p$-dioxins and dibenzofurans in surficial sediments from Newark Bay, New Jersey. Chemosphere 27:55-64 
Wilk SJ, McMillan DG, Pikanowski RA, MacHaffie EM, Pacheco AL, Stehlik LL (1997) Fish, mega invertebrates, and associated hydrographic observations collected in Newark Bay, New Jersey during May 1993-April 1994. Northeast Fisheries Science Center Reference Document 97-10, June 1997, National Marine Fisheries Service, Highlands, NJ

Wirgin I, Maceda L, Grunwald C, King T (2015) Population origin of Atlantic sturgeon bycaught in U. S. Atlantic coast fisheries. J Fish Biol 85:1-20

Wirgin I, Roy NK, Loftus M, Chambers RC, Franks DG, Hahn ME (2011) Mechanistic basis of resistance to PCBs in Atlantic tomcod from the Hudson River, USA. Science 331:1322-1325

\section{Tables}

Table 1. Collection details of Hudson River shortnose sturgeon and Atlantic sturgeon used in this study to quantify hepatic PCB and PCDD/F burdens. All fish collected in the 2010's were either live with liver samples taken by biopsy or recent fatalities. Fish from 1984 were museum specimens that had been fixed in formalin and later preserved in ethanol. Abbreviations: SS, shortnose sturgeon; AS, Atlantic sturgeon; Rkm, river kilometer (km upstream from The Battery, southern Manhattan, New York).

\begin{tabular}{|c|c|c|c|c|c|}
\hline c & & & & & c \\
\hline & Collection & & & & \\
\hline Species & Location & Rkm & Date & TL & Specimen status \\
\hline SS & Nyack & 43 & $8 / 13 / 2015$ & 80.0 & fatality \\
\hline SS & Haverstraw & 63 & $8 / 28 / 2016$ & - & fatality \\
\hline SS & Haverstraw & 63 & $9 / 16 / 2014$ & 65.5 & live \\
\hline SS & Haverstraw & 63 & 9/16/2014 & 79.1 & live \\
\hline SS & Haverstraw & 63 & $9 / 16 / 2014$ & 88.3 & live \\
\hline SS & Indian Point & 69 & $5 / 21 / 1984$ & 46.6 & preserved \\
\hline SS & Indian Point & 69 & $3 / 22 / 1984$ & 55.6 & preserved \\
\hline SS & Albany & 229 & $6 / 28 / 1984$ & 33.3 & preserved \\
\hline AS & Nyack & 43 & $8 / 31 / 2015$ & 42.7 & fatality \\
\hline AS & Haverstraw & 58 & $4 / 18 / 2016$ & 74.7 & live \\
\hline AS & Haverstraw & 61 & 4/19/2016 & 73.4 & live \\
\hline AS & Haverstraw & 63 & 4/18/2016 & 76.5 & live \\
\hline AS & Haverstraw & 63 & $4 / 18 / 2016$ & 63.3 & live \\
\hline
\end{tabular}

Table 2. Descriptive statistics, between-group tests, and trends of differences for 12 dioxin-like PCB congeners, 3 inadvertent PCB congeners, and total PCBs $(\mathrm{pg} / \mathrm{g}-\mathrm{ww})$ in livers of shortnose sturgeon and Atlantic sturgeon collected from the Hudson River. Type II error is shown for all tests with $p \leq 0.1$. The number of tests that was significant $(p \leq 0.05)$ and in the direction specified in the Summary heading (bottom of table), out of all tests conducted on individual congeners and total (all) PCB congeners, also includes observations below levels of detectability. 'Trend' is the number of cases for which the means are in the direction stated in the Summary heading compared to the total number of tests conducted. Trends are also reflected in the overall magnitude of differences between groups (e.g., archived vs. recent, or shortnose sturgeon vs. Atlantic sturgeon) as quantified by the ratio of the grand means (congeners and total PCB) between contrasted groups ( $\mathrm{N}=2$ a minimum for inclusion). Abbreviations: $n d$, non-detectible; $N S$, not significant $(p>0.05)$; na, not available. 


\begin{tabular}{|c|c|c|c|c|c|c|c|c|c|c|c|c|c|c|c|}
\hline \multirow{2}{*}{$\begin{array}{l}\text { PCBs } \\
\text { Coplanar } \\
\text { PCBs }\end{array}$} & \multicolumn{3}{|c|}{$\begin{array}{l}\text { Shortnose sturgeon } \\
\text { (recent) }\end{array}$} & \multicolumn{3}{|c|}{$\begin{array}{l}\text { Shortnose sturgeon } \\
\text { (archive) }\end{array}$} & \multicolumn{3}{|c|}{ Atlantic sturgeon } & \multicolumn{3}{|c|}{$\begin{array}{l}\text { Shortnose sturgeon } \\
\text { (archive vs. recent) }\end{array}$} & \multicolumn{3}{|c|}{$\begin{array}{l}\text { Shortnose sturgeon } \\
\text { vs. Atlantic } \\
\text { sturgeon }\end{array}$} \\
\hline & Mean & SEM & $\begin{array}{l}\mathrm{N} \\
(n d)\end{array}$ & Mean & SEM & $\begin{array}{l}\mathrm{N} \\
(n d)\end{array}$ & Mean & SEM & $\begin{array}{l}\mathrm{N} \\
(n d)\end{array}$ & $\mathrm{F}$ & df & $\mathrm{p}$ & $\mathrm{F}$ & df & $p$ \\
\hline 77 & 1,032 & 123 & 5 & 969 & 534 & 3 & 349 & 274 & 5 & 0.02 & 1,6 & NS & 5.17 & 1,8 & 0.05 \\
\hline 81 & 71.7 & 9.48 & 5 & 210 & 147 & 3 & 8.7 & 8.74 & $\begin{array}{l}5 \\
(4)\end{array}$ & 1.64 & 1,6 & NS & 23.81 & 1,8 & $<.01$ \\
\hline 126 & 0 & 0 & $\begin{array}{l}5 \\
(5)\end{array}$ & 12.8 & 12.80 & $\begin{array}{l}3 \\
(2)\end{array}$ & 0 & 0 & $\begin{array}{l}5 \\
(5)\end{array}$ & 1.88 & 1,6 & NS & - & - & - \\
\hline 169 & 0 & 0 & $\begin{array}{l}5 \\
(5)\end{array}$ & 0 & 0 & $\begin{array}{l}3 \\
(3)\end{array}$ & 0 & 0 & $\begin{array}{l}5 \\
(5)\end{array}$ & - & - & - & - & - & - \\
\hline 105 & 50,180 & 7,566 & 5 & 10,600 & . & 1 & 8,076 & 2,247 & 5 & 4.56 & 1,4 & NS & 28.46 & 1,8 & $\begin{array}{l}< \\
0.01\end{array}$ \\
\hline 114 & 4,612 & 767 & 5 & 16,143 & 9,889 & 3 & 635 & 141 & 5 & 2.45 & 1,6 & NS & 26.02 & 1,8 & $<0.01$ \\
\hline 118 & 96,725 & 10,389 & 4 & 33,100 & . & 1 & 18,630 & 9,809 & 5 & 7.50 & 1,3 & NS & 29.47 & 1,7 & 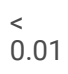 \\
\hline 123 & 1,028 & 205 & 5 & 7,279 & 4,493 & 3 & 265 & 151 & 5 & 3.60 & 1,6 & NS & 8.961 & 1,8 & 0.02 \\
\hline $156 / 7$ & 37,760 & 6,941 & 5 & 48,097 & 27,378 & 3 & 6,218 & 1,592 & 5 & 0.22 & 1,6 & NS & 19.62 & 1,8 & $<0.01$ \\
\hline 167 & 1,294 & 170 & 5 & 1,932 & 969 & 3 & 436 & 327 & 5 & 0.74 & 1,6 & NS & 5.42 & 1,8 & 0.05 \\
\hline 189 & 3,732 & 644 & 5 & 3,283 & 1,606 & 3 & 714 & 128 & 5 & 0.10 & 1,6 & NS & 21.11 & 1,8 & $<.01$ \\
\hline \multicolumn{16}{|l|}{$\begin{array}{l}\text { Inadvertent } \\
\text { PCBs }\end{array}$} \\
\hline 5 & 3.9 & 2.53 & $\begin{array}{l}5 \\
(3)\end{array}$ & 48.3 & 32.74 & 3 & 0.47 & 0.47 & $\begin{array}{l}5 \\
(4)\end{array}$ & 3.39 & 1,6 & NS & 1.75 & 1,8 & NS \\
\hline 11 & 398 & 128 & 5 & 90.5 & 32.04 & 3 & 59.9 & 25.49 & 5 & 3.18 & 1,6 & NS & 6.71 & 1,8 & 0.03 \\
\hline 52 & 346,250 & 23,558 & $\begin{array}{l}4 \\
(0)\end{array}$ & 85,100 & na & 1 & 64,300 & 31,326 & 5 & 24.52 & 1,3 & 0.02 & 47.01 & 1,7 & $\begin{array}{l}< \\
0.01\end{array}$ \\
\hline \multirow[t]{6}{*}{ Total PCBs } & 8.60 & 1.44 & 5 & 12.17 & 7.88 & 3 & 1.48 & 1.26 & 5 & 0.35 & 1,6 & NS & 22.19 & 1,8 & $<.01$ \\
\hline & $x 10^{6}$ & $x 10^{6}$ & & $x 10^{6}$ & $x 10^{6}$ & & $x 10^{6}$ & $x 10^{6}$ & & & & & & & \\
\hline & & & & & & & & \multicolumn{2}{|c|}{ Summary: } & \multicolumn{3}{|c|}{ archive $>$ recent } & \multicolumn{3}{|c|}{ shortnose > Atlantic } \\
\hline & & & & & & & & \multicolumn{2}{|c|}{ Significance test: } & \multicolumn{3}{|c|}{0 of 13} & \multicolumn{3}{|c|}{12 of 13} \\
\hline & & & & & & & & \multicolumn{2}{|l|}{ Trend: } & \multicolumn{3}{|c|}{7 of 11} & \multicolumn{3}{|c|}{12 of 12} \\
\hline & & & & & & \multicolumn{4}{|c|}{ Ratio of grand means: } & \multicolumn{3}{|l|}{3.2} & \multicolumn{3}{|l|}{5.5} \\
\hline
\end{tabular}

Table 3. Descriptive statistics, between-group tests, and trends of differences in 7 PCCD congeners (pg/g-ww) in livers of shortnose sturgeon and Atlantic sturgeon collected from the Hudson River. Type II error shown for all tests with $p \leq 0.1$. See Table 2 for interpretation of summary on significance tests, trends, and ratios of grand means. Abbreviations: $n d$, non-detectible; $N S$, not significant $(p>0.05)$. 


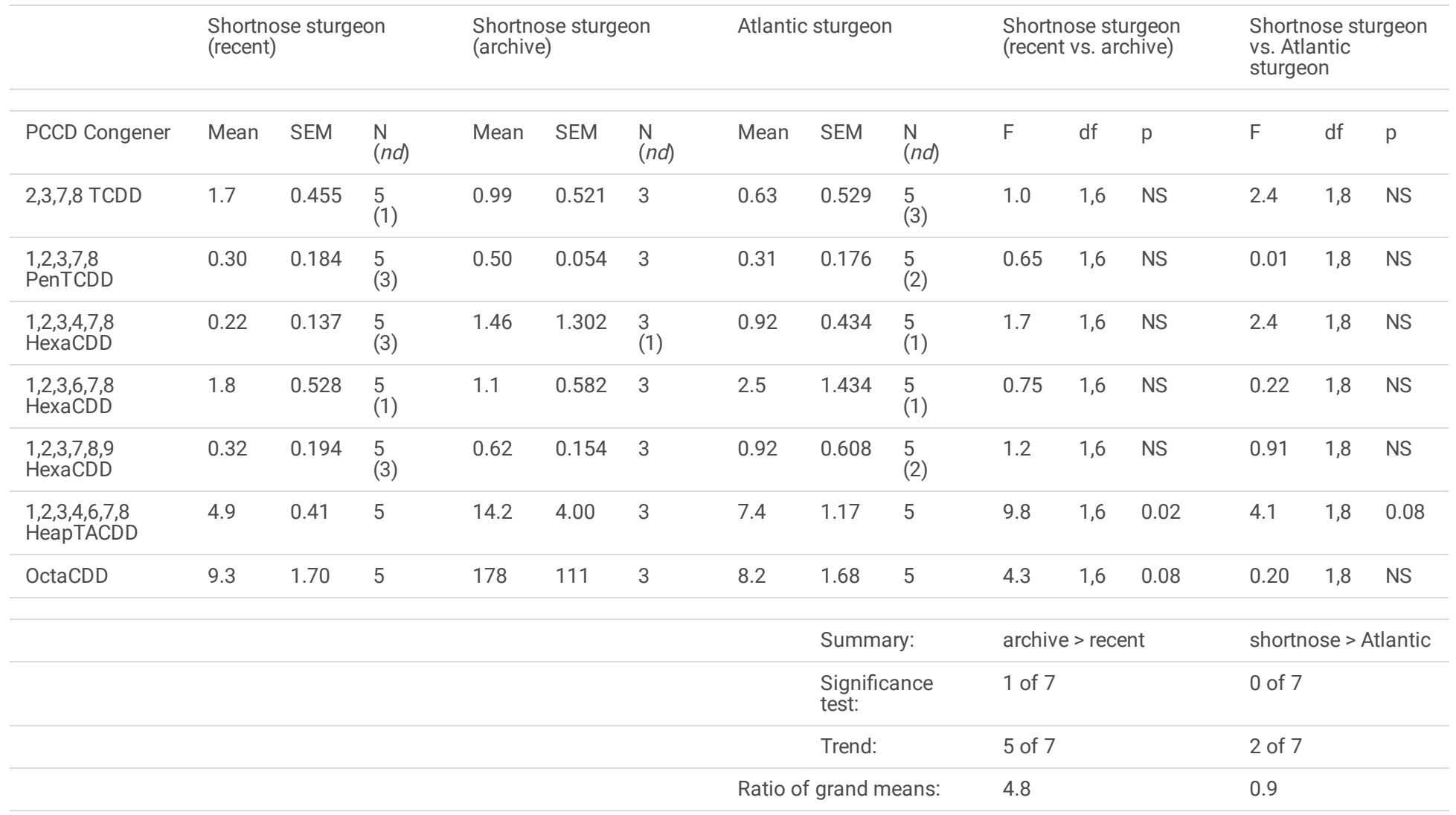

Table 4. Descriptive statistics, between-group tests, and trends of differences for 10 PCDF congeners (pg/g-ww) in livers of shortnose sturgeon and Atlantic sturgeon collected from the Hudson River. Type II error shown for all tests with $p \leq 0.1$. See Table 2 for interpretation of summary on significance tests, trends, and ratios of grand means. Abbreviations: $n d$, non-detectible; $N S$, not significant $(p>0.05)$. 


\begin{tabular}{|c|c|c|c|c|c|c|c|c|c|c|c|c|c|c|c|}
\hline \multirow[b]{2}{*}{$\begin{array}{l}\text { PCCD } \\
\text { Congener }\end{array}$} & \multicolumn{3}{|c|}{$\begin{array}{l}\text { Shortnose sturgeon } \\
\text { (recent) }\end{array}$} & \multicolumn{3}{|c|}{$\begin{array}{l}\text { Shortnose sturgeon } \\
\text { (archive) }\end{array}$} & \multicolumn{3}{|c|}{ Atlantic sturgeon } & \multicolumn{3}{|c|}{$\begin{array}{l}\text { Shortnose sturgeon } \\
\text { (recent vs. archive) }\end{array}$} & \multicolumn{3}{|c|}{$\begin{array}{l}\text { Shortnose sturgeon } \\
\text { vs. Atlantic sturgeon }\end{array}$} \\
\hline & Mean & SEM & $\begin{array}{l}\mathrm{N} \\
(n d)\end{array}$ & Mean & SEM & $\stackrel{\mathrm{N}}{(n d)}$ & Mean & SEM & $\stackrel{\mathrm{N}}{(n d)}$ & $\mathrm{F}$ & df & $\mathrm{p}$ & $\mathrm{F}$ & df & $\mathrm{p}$ \\
\hline $\begin{array}{l}2,3,7,8 \\
\text { TetraCDF }\end{array}$ & 26.2 & 4.63 & 5 & 20.0 & 11.54 & 3 & 11.1 & 4.18 & 5 & 0.35 & 1,6 & NS & 5.8 & 1,8 & 0.04 \\
\hline $\begin{array}{l}1,2,3,7,8 \\
\text { PentaCDF }\end{array}$ & 1.2 & 0.42 & $\begin{array}{l}5 \\
(1)\end{array}$ & 1.7 & 0.89 & 3 & 1.4 & 0.81 & $\begin{array}{l}5 \\
(1)\end{array}$ & 0.38 & 1,6 & NS & 0.06 & 1,8 & NS \\
\hline $\begin{array}{l}2,3,4,7,8 \\
\text { PentaCDF }\end{array}$ & 6.3 & 0.85 & 5 & 4.9 & 2.66 & 3 & 2.3 & 0.80 & 5 & 0.39 & 1,6 & NS & 11.6 & 1,8 & $<0.01$ \\
\hline $\begin{array}{l}\text { 1,2,3,4,7,8 } \\
\text { HexaCDF }\end{array}$ & 0.25 & 0.161 & $\begin{array}{l}5 \\
(3)\end{array}$ & 0.79 & 0.300 & 3 & 0.94 & 0.444 & $\begin{array}{l}5 \\
(1)\end{array}$ & 3.1 & 1,6 & NS & 2.2 & 1,8 & NS \\
\hline $\begin{array}{l}\text { 1,2,3,6,7,8 } \\
\text { HexaCDF }\end{array}$ & 1.1 & 0.53 & $\begin{array}{l}5 \\
(2)\end{array}$ & 0.48 & 0.282 & $\begin{array}{l}3 \\
(1)\end{array}$ & 1.0 & 0.55 & $\begin{array}{l}5 \\
(1)\end{array}$ & 0.74 & 1,6 & NS & 0.01 & 1,8 & NS \\
\hline $\begin{array}{l}1,2,3,7,8,9 \\
\text { HexaCDF }\end{array}$ & 0.17 & 0.168 & $\begin{array}{l}5 \\
(4)\end{array}$ & 0 & 0 & $\begin{array}{l}3 \\
(3)\end{array}$ & 0 & 0 & $\begin{array}{l}5 \\
(5)\end{array}$ & 0.56 & 1,6 & NS & 1.0 & 1,8 & NS \\
\hline $\begin{array}{l}2,3,4,6,7,8 \\
\text { HexaCDF }\end{array}$ & 0.18 & 0.110 & $\begin{array}{l}5 \\
(3)\end{array}$ & 0.25 & 0.142 & $\begin{array}{l}3 \\
(1)\end{array}$ & 0.30 & 0.192 & $\begin{array}{l}5 \\
(2)\end{array}$ & 0.16 & 1,6 & NS & 0.28 & 1,8 & NS \\
\hline $\begin{array}{l}1,2,3,4,6,7,8 \\
\text { НераCDF }\end{array}$ & 0.96 & 0.258 & $\begin{array}{l}5 \\
(1)\end{array}$ & 10.5 & 8.96 & 3 & 2.3 & 1.21 & $\begin{array}{l}5 \\
(1)\end{array}$ & 2.1 & 1,6 & NS & 1.2 & 1,8 & NS \\
\hline $\begin{array}{l}\text { 1,2,3,4,7,8,9 } \\
\text { HepaCDF }\end{array}$ & 0.05 & 0.047 & $\begin{array}{l}5 \\
(4)\end{array}$ & 0.49 & 0.215 & 3 & 0.08 & 0.080 & $\begin{array}{l}5 \\
(4)\end{array}$ & 7.0 & 1,6 & 0.04 & 0.13 & 1,8 & NS \\
\hline \multirow[t]{5}{*}{ OCDF } & 0.26 & 0.260 & $\begin{array}{l}5 \\
(4)\end{array}$ & 68.5 & 66.23 & 3 & 0.41 & 0.223 & $\begin{array}{l}5 \\
(1)\end{array}$ & 2.0 & 1,6 & NS & 0.20 & 1,8 & NS \\
\hline & & & & & & & & \multicolumn{2}{|c|}{ Summary: } & \multicolumn{3}{|c|}{ archive $>$ recent } & \multicolumn{3}{|c|}{ shortnose $>$ Atlantic } \\
\hline & & & & & & & & \multicolumn{2}{|c|}{$\begin{array}{l}\text { Significance } \\
\text { test: }\end{array}$} & \multicolumn{3}{|c|}{1 of 10} & \multicolumn{3}{|c|}{2 of 10} \\
\hline & & & & & & & & \multicolumn{2}{|l|}{ Trend: } & \multicolumn{3}{|c|}{6 of 10} & \multicolumn{3}{|c|}{4 of 10} \\
\hline & & & & & & & \multicolumn{3}{|c|}{ Ratio of grand means: } & \multicolumn{3}{|l|}{2.9} & \multicolumn{3}{|l|}{1.5} \\
\hline
\end{tabular}

Table 5. Summary statistics and between-group tests and trends of differences for levels of hepatic PCB Toxic Equivalency Quotients (TEQs), PCDD/Fs TEQs, and total TCDD TEQs in livers of shortnose sturgeon and Atlantic sturgeon collected from the Hudson River. TEFs values used are those for fishes from Van den Berg et al. (1998). Type II error shown for all tests with $p \leq 0.1$. Abbreviations: NS, not significant; $p>0.05$.

\begin{tabular}{|c|c|c|c|c|c|c|c|c|c|c|c|c|c|c|c|}
\hline & \multicolumn{3}{|c|}{$\begin{array}{l}\text { Shortnose sturgeon } \\
\text { (recent) }\end{array}$} & \multicolumn{3}{|c|}{$\begin{array}{l}\text { Shortnose sturgeon } \\
\text { (archive) }\end{array}$} & \multicolumn{3}{|c|}{ Atlantic sturgeon } & \multicolumn{3}{|c|}{$\begin{array}{l}\text { Shortnose sturgeon } \\
\text { (recent vs. archive) }\end{array}$} & \multicolumn{3}{|c|}{$\begin{array}{l}\text { Shortnose sturgeon vs. } \\
\text { Atlantic sturgeon }\end{array}$} \\
\hline TEQ & Mean & SEM & $\mathrm{N}$ & Mean & SEM & $\mathrm{N}$ & Mean & SEM & $\mathrm{N}$ & $\mathrm{F}$ & df & $\mathrm{p}$ & $\mathrm{F}$ & df & $\mathrm{p}$ \\
\hline PCBs & 1.6 & 0.27 & 5 & 4.0 & 2.36 & 3 & 0.3 & 0.108 & 5 & 2.0 & 1,6 & NS & 18.9 & 1,8 & $<0.01$ \\
\hline $\mathrm{PCDD} / \mathrm{Fs}$ & 6.6 & 0.95 & 5 & 5.0 & 2.29 & 3 & 3.5 & 1.12 & 5 & 0.60 & 1,6 & NS & 4.5 & 1,8 & 0.07 \\
\hline $\begin{array}{l}\text { Total } \\
\text { TEQs }\end{array}$ & 8.2 & 1.19 & 5 & 9.0 & 4.64 & 3 & 3.8 & 1.21 & 5 & 0.05 & 1,6 & NS & 6.6 & 1,8 & 0.03 \\
\hline
\end{tabular}

Table 6. Summary statistics and between-group tests and trends of differences for TCDD Toxic Equivalency Quotients (TEQs) of 2,3,7,8 TCDF, 2,3,4,7,8 PeCDF and their sum in shortnose sturgeon and Atlantic sturgeon livers collected from the Hudson River. TEQs are based on RePs developed by Eisner et al. (2016) in white sturgeon livers for 2,3,7,8 TCDF (1.4) and 2,3,4,7,8 PeCDF (1.2). Type Il error shown for all tests with $p \leq 0.1$. Abbreviations: nd, non-detectible; NS, not significant, $p>0.05$. 


\begin{tabular}{|c|c|c|c|c|c|c|c|c|c|c|c|c|c|c|c|}
\hline & \multicolumn{3}{|c|}{$\begin{array}{l}\text { Shortnose sturgeon } \\
\text { (recent) }\end{array}$} & \multicolumn{3}{|c|}{$\begin{array}{l}\text { Shortnose sturgeon } \\
\text { (archive) }\end{array}$} & \multicolumn{3}{|c|}{ Atlantic sturgeon } & \multicolumn{3}{|c|}{$\begin{array}{l}\text { Shortnose sturgeon } \\
\text { (recent vs. archive) }\end{array}$} & \multicolumn{3}{|c|}{$\begin{array}{l}\text { Shortnose sturgeon } \\
\text { vs. Atlantic sturgeon }\end{array}$} \\
\hline TEQ & Mean & SEM & $\begin{array}{l}\mathrm{N} \\
(n d)\end{array}$ & Mean & SEM & $\begin{array}{l}\mathrm{N} \\
(n d)\end{array}$ & Mean & SEM & $\stackrel{\mathrm{N}}{(n d)}$ & $\mathrm{F}$ & df & $p$ & $\mathrm{~F}$ & df & $p$ \\
\hline $\begin{array}{l}\text { A) } 2,3,7,8 \\
\text { TCDF }\end{array}$ & 36.65 & 4.63 & 5 & 27.85 & 11.54 & 3 & 15.58 & 4.18 & 5 & 0.35 & 1,6 & NS & 5.8 & 1,8 & 0.04 \\
\hline $\begin{array}{l}\text { B) } 2,3,4,7,8 \\
\text { PeCDF }\end{array}$ & 7.51 & 0.85 & 5 & 5.83 & 2.66 & 3 & 2.75 & 0.80 & 5 & 0.39 & 1,6 & NS & 11.6 & 1,8 & $<0.01$ \\
\hline Total $(A+B)$ & 44.16 & 5.45 & 5 & 33.68 & 14.20 & 3 & 18.33 & 4.70 & 5 & 0.36 & 1,6 & NS & 7.0 & 1,8 & 0.03 \\
\hline
\end{tabular}

Table 7. Minimal nominal waterborne concentrations (ppb) of PCB126 and 2,3,7,8 TCDD that induced significant early-life toxicities (Chambers et al. 2012) and induction of CYP1A mRNA expression (Roy et al. 2011) in larval shortnose sturgeon and Atlantic sturgeon exposed as embryos under controlled laboratory conditions. Nominal waterborne doses of PCB126 ranged from 0.01 to 1,000 ppb and 2,3,7,8 TCDD from 0.001 to 100 ppb. TEFs were calculated as the ratio between concentrations of 2,3,7,8 TCDD and PCB126 eliciting an effect in each of the measured responses. Abbreviations: $N E$, no effect; $N A$. not applicable.

\begin{tabular}{|c|c|c|c|c|c|c|}
\hline \multirow[t]{4}{*}{ Early life-stage toxicities } & \multicolumn{3}{|c|}{ Shortnose sturgeon } & \multicolumn{3}{|c|}{ Atlantic sturgeon } \\
\hline & - & - & & & - & - \\
\hline & РCB 126 & 2,3,7,8 TCDD & TEF & PCB 126 & 2,3,7,8 TCDD & TEF \\
\hline & - & - & & & - & - \\
\hline Embryo survival & $\geq 10$ & $\geq 1$ & 0.1 & $\geq 100$ & $\geq 1$ & 0.01 \\
\hline Embryo period duration & NE & NE & NA & NE & NE & NA \\
\hline Length (larvae) & $\geq 1$ & $\geq 0.01$ & 0.01 & $\geq 0.1$ & $\geq 0.01$ & 0.1 \\
\hline Development (eye) & $\geq 0.01$ & $\geq 0.001$ & 0.1 & $\geq 1$ & $\geq 0.1$ & 0.1 \\
\hline Larval lifespan (unfed) & $\geq 0.1$ & $\geq 0.01$ & 0.1 & $\geq 0.1$ & $\geq 0.01$ & 0.1 \\
\hline CYP1A mRNA Induction & $\geq 0.01$ & $\geq 0.001$ & 0.1 & $\geq 0.01$ & $\geq 0.001$ & 0.1 \\
\hline
\end{tabular}

\section{Figures}




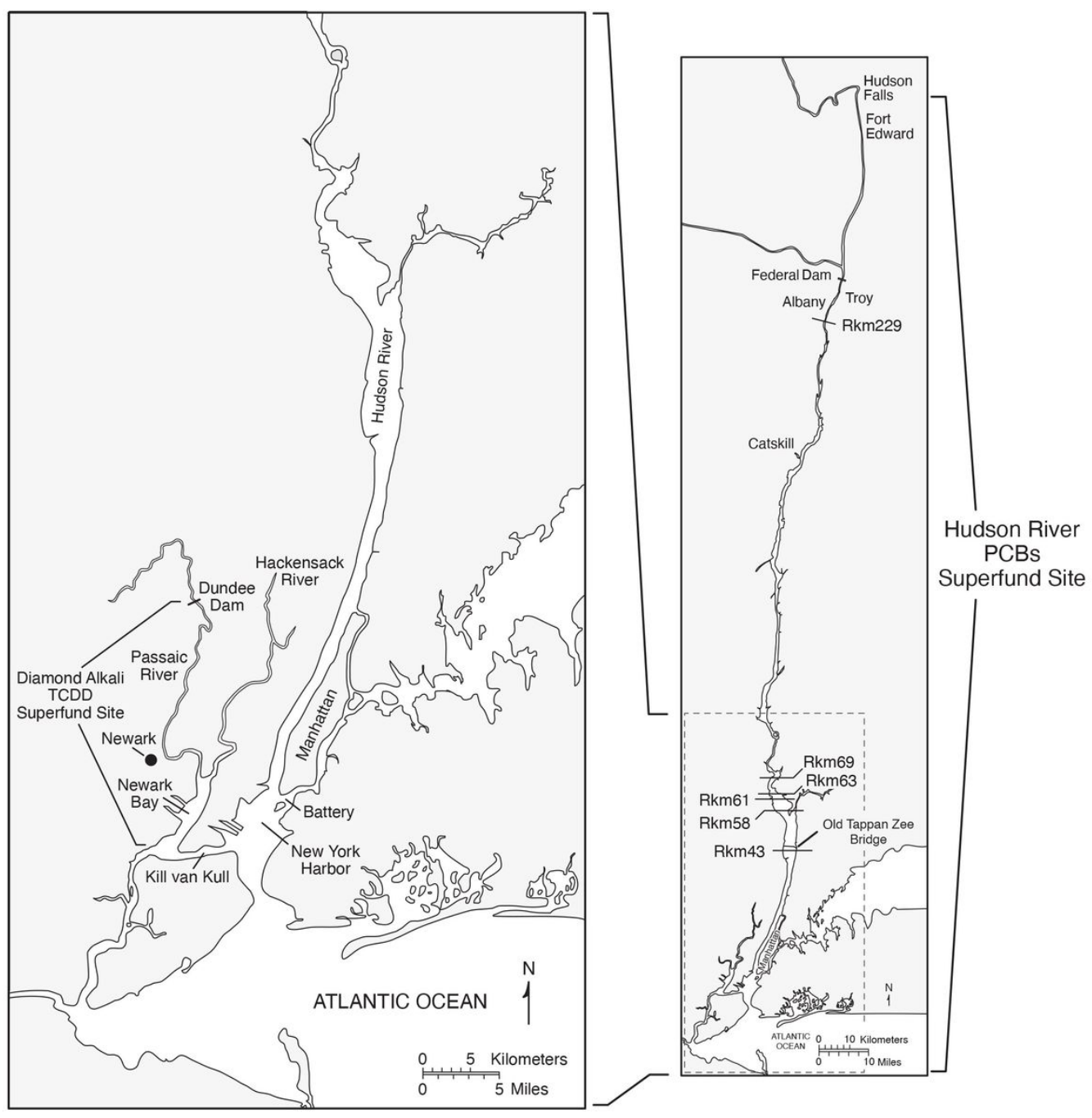

Figure 1

Newark Bay is contiguous with the HR via the Kill van Kull and New York Harbor

\section{Supplementary Files}

This is a list of supplementary files associated with this preprint. Click to download.

- NOAASampTisssturgeon.xlsx

- V63886DXDatabase1.xIsx

- V63886PCBDatabase1.xlsx 